\title{
Mechanical Behavior and Failure of Riveting Joints in Tensile and Shear Tests
}

\section{J. Mucha ${ }^{1}$ and W. Witkowski}

Faculty of Mechanical Engineering and Aeronautics, Rzeszow University of Technology, Rzeszow, Poland

${ }^{1}$ j_mucha@prz.edu.pl

УДК 539.4

\section{Механические характеристики и разрушение заклепочных соединений при статических испытаниях на растяжение и сдвиг}

\section{Я. Муха, В. Витковский}

Факультет машиностроения и аэронавтики, Технологический университет г. Ржешов, Польша

Основным критерием прочности заклепочных соединений при их разработке является сопротивление материала заклепок сдвиговому нагружению. При испытании на сдвиг обычных заклепочных соединений определяющими являются механические характеристики материала заклепки. Поэтому необходимо описание механизма разрушения различных соединений при испьтаниях на растяжение. Оченивается прочность разных листовых материалов (сталь DC01, алюминиевый сплав $A W-5754$ и их комбинация) в заклепочном соединении. Анализируется механизм разрушения заклепочных соединений при одноосном растяжении Т-образных образиов из различных листовых материалов. Выполнено сравнение экспериментальных результатов, полученных при растяжении и сдвиге заклепочных соединений внахлестку для одного и того же типа.

Ключевые слова: испытания на растяжение, прочность при сдвиге, разрушение заклепочных соединений, заклепки самопробивного типа.

Introduction. Selection of the optimal materials for construction of thin-walled structures is currently in a transient phase. The elements, which previously have been manufactured from steel, are now increasingly made of fiber-reinforced plastic and alloy of light metals, such as aluminum and magnesium. The new materials generate the need for the development of appropriate joining technologies. The use of the new material types forced the use of alternative joining technologies, in comparison to traditional connecting techniques. This implies the need for experimental studies related to the evaluation of the formation and strength of new joints. New solutions are not always good enough to provide an adequate strength. In some cases, formation for new materials' joints is quite problematic. Hence, the classic riveting technologies with the blind rivet or with the blind hermetic rivet are still widely applied and will probably continue to be used in the future. In the industry of public utility buildings and residential houses, these joints are the most widely used because of their high degree of certainty. Thin profiles are joined by means of various fasteners, usually by blind rivets [1-4] or, in case of composite structures, either by screws [5-7] or by special tubular rivets [8-11]. The self-piercing riveting technology is also commonly used [12-18]. There are few variations in the technology of their formation. One of them is a solid self-piercing riveting (SSPR) technology proposed by Kerb-KonusVertriebs-GmbH company [19]. During the formation of clinching, self-piercing riveting or 
clinching riveting joints the material can fracture, especially the bottom sheet from the die side. These joint types are characterized by embossments, which depend on the forming process. The SSPR joining technology provides a flat surface on the rivet punching side [20-22]. This also allows one to effectively join materials of various mechanical properties, e.g., soft materials with hard ones [23].

Notwithstanding the fact that many scientists have published their results of the research, most of them are related to static shear tests or the fatigue tests of the riveting lap joints [1-16]. A number of international standards define dimensions, testing conditions and the fracture mechanism of lap joints [24-26]. The main types of lap joint separation during shear tests (Fig. 1) were included in the aforementioned standards and their descriptions can be found in various scientific papers. However, there are only few papers related to comparing the joint strength during a unilateral tensile test. One of the relevant publications is the study [27] of SPR joints. The results of the multiaxial joint strength and discussion of these results were presented in work [28]. One of the first papers, which contain a comprehensive analysis of the joint shear and tensile test results, was related to the solid self-piercing riveting joints [20]. Bartczak et al. have also studied the joint strength of H-shaped specimens during tensile tests. In paper [29], they analyzed the effect of welded joint strengthened by adhesive on the absorption of fracture energy. Mucha and Witkowski [30] presented a comprehensive analysis of the strength of clinching joints in multiaxial loading conditions.

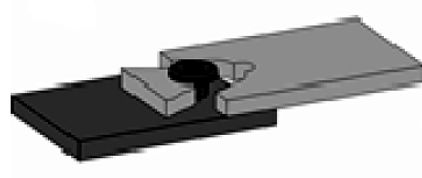

a

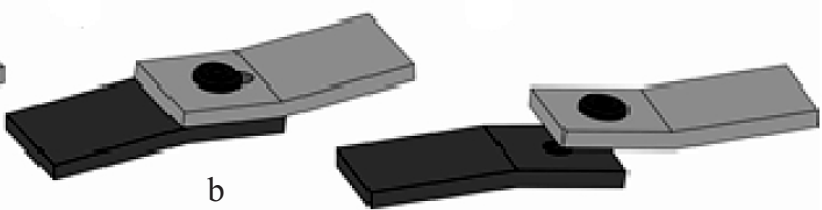

C
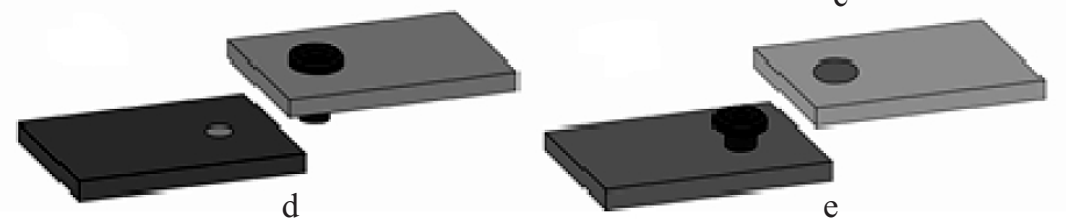

Fig. 1. Failure types of riveting joints according to the standard ISO/FDIS 12996: (a) failure of the specimen material; (b) impermissible specimen deformation; (c) fastener failure; (d) fastener pull- out from bottom sheet; (e) pull-out of fastener head.

In case of shear of the riveting joints, the rivet material determines the strength of joints. These joints are designed with consideration of the strength of fasteners. Hence, it is expedient to identify the fracture mechanism for various joints in tensile tests. The strength analysis of various riveting joints extends the knowledge needed for their designing. The presented results of the analysis can be helpful in designing the joints used for assembling thin-walled sheet structures.

The paper discusses the influence of sheet material type on the strength of joints in unilateral tensile tesst of standard riveting joints and new joints with SSPR. The obtained results are compared with those obtained from the shear tests of lap joints. In both cases, the same types of rivets are used.

1. Methodology and Materials. The impact of the arrangement of sheet material on the force-displacement curves constructed during shear and tensile tests for various riveting technologies was experimentally studied. The mechanism of fracture during the tests on the maximum load-bearing capacity of joints was also analyzed. For this analysis, four types of riveting joint were selected. The fasteners were: blind rivet (BR), blind 


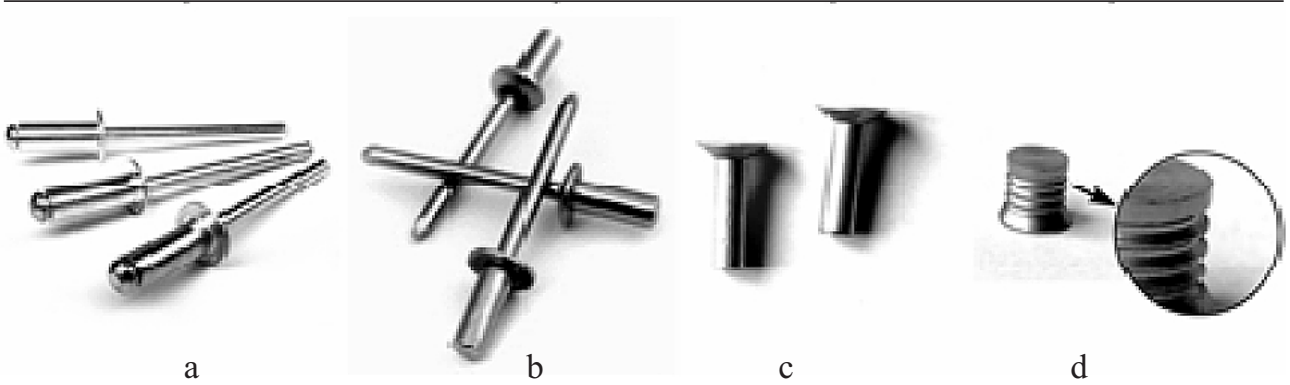

Fig. 2. Fasteners used in riveting joints: (a) aluminum-steel BR; (b) aluminum-steel BHR; (c) aluminum alloy COUR; (d) steel SSPR.

hermetic rivet (BHR), closing-up rivet (COUR), and SSPR (see Fig. 2). Rivet length, rivet diameter, hole diameter, and squeeze force are major parameters that affect the quality of formed rivets [31]. All rivets had the same diameter of cylindrical parts $d_{r}=4 \mathrm{~mm}$, and the remaining geometry was selected for the total thickness of joined sheets $t_{t o t}=4 \mathrm{~mm}$. For the proper insertion of rivets for closing up, there were chamfers prepared in the holes on one side of the sheets during the joining process. The specimens were prepared according to the joining industrial conditions.

For the experiments, the sheet materials were made of DC01 steel (material number 1.0330) and aluminum alloy in O/H111 state (material number 3.3535). The yield strength values of these materials were 160 and $85 \mathrm{MPa}$, respectively, while the respective tensile strength values were 290 and $220 \mathrm{MPa}$. The thickness of each sheet was the same $(2 \mathrm{~mm})$. The specimens (Fig. 3) were prepared in accordance with the recommendations included in ISO/FDIS 12996 standard [24]. The selected sheet arrangements for the tensile and shear tests are tabulated in Table 1. All joints were prepared carefully in identical conditions of their formation. In the hybrid arrangements of sheet materials, the primary rivet head was positioned in the steel sheet (Fig. 3), while the secondary rivet head was formed on the aluminum alloy sheet side. For all joints, the static shear tests (lap joints) and tensile tests (T-shaped specimens) were performed with the force-displacement curves recorded via an Instron 3382 testing machine. The traversing speed of the machine traverse was $10 \mathrm{~mm} / \mathrm{min}$. The displacements in shear and tensile tests were recorded using the extensometer system with the measuring distance of $60 \mathrm{~mm}$, as shown in Fig. 3b. There were seven specimens prepared for each arrangement of sheets and types of rivets.

T a b 1 e 1

Fasteners and Sheet Material Combinations Used in Riveting Joints

\begin{tabular}{|c|c|c|c|c|c|}
\hline \multicolumn{2}{|c|}{ Sheet material } & \multicolumn{4}{|c|}{ Fastener } \\
\hline & & $\mathrm{BHR}^{1}$ & $\mathrm{BR}^{2}$ & $\mathrm{COUR}^{3}$ & $\mathrm{SSPR}^{4}$ \\
\hline Steel & DC01/DC01 & $1-1$ & $1-2$ & $1-3$ & $1-4$ \\
\hline $\begin{array}{c}\text { Hybrid } \\
\text { (steel-aluminum) }\end{array}$ & DC01/AW-5754 & $2-1$ & $2-2$ & $2-3$ & $2-4$ \\
\hline Aluminum & AW-5754/AW-5754 & $3-1$ & $3-2$ & $3-3$ & $3-4$ \\
\hline
\end{tabular}

${ }^{1}$ ISO 15974:2003; ${ }^{2}$ ISO 15978:2003; ${ }^{3}$ ISO 1051:1999; ${ }^{4}$ Catalog No. 492000007.900 [19]. 


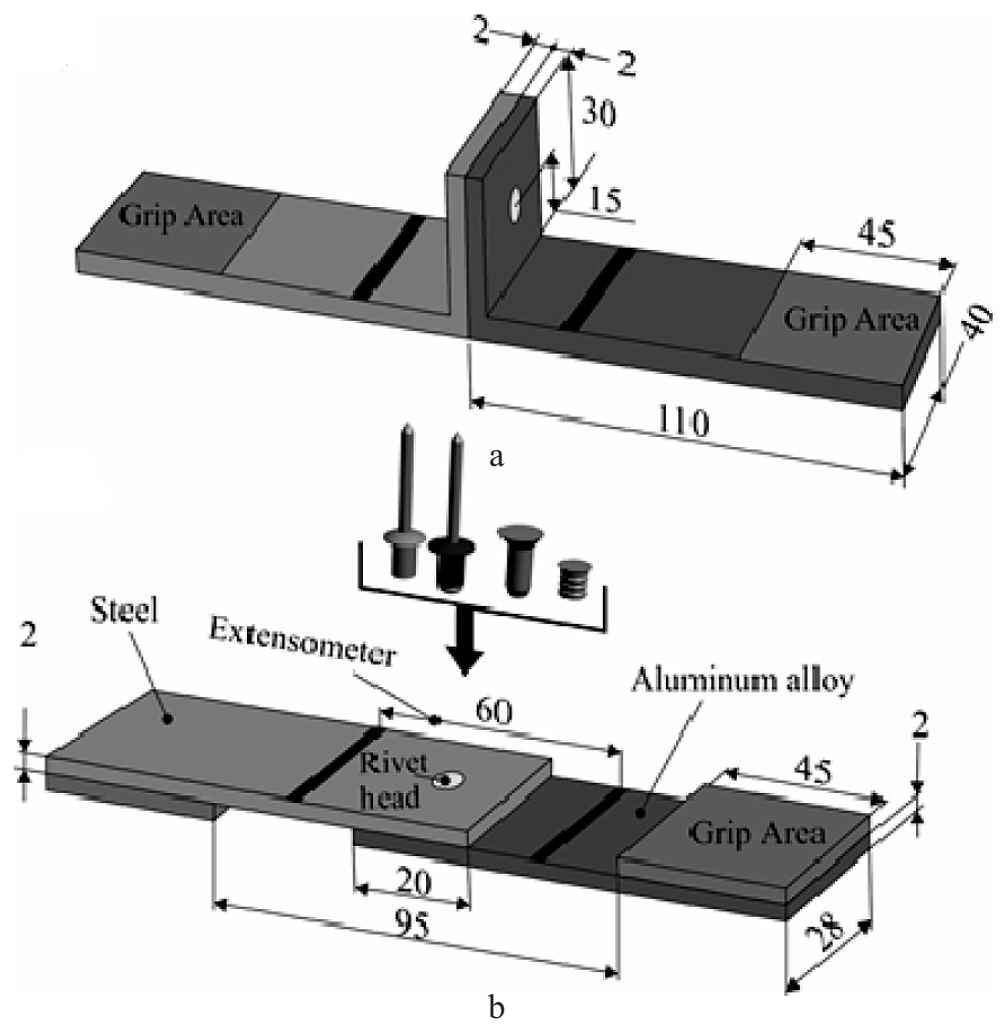

Fig. 3. The specimen geometry and the rivet position in the hybrid connection: (a) T-shaped specimen joint; (b) lap joint.

\section{Results and Discussion.}

2.1. Riveting Joint Failure in the Tensile Test. The standards for tensile tests envision a specific procedure of joint preparation and test conditions. Joints should be located in sheet structures to transmit the shear load. However, in many cases, this is not possible. Hence, tensile tests of joints are an equally important issue. At present, there are no guidelines, such as standards, for the preparation and geometry of riveting joint specimens used in tensile tests. In case of a unilateral tensile test of T-shaped specimens, a rivet is uniformly loaded at the initial loading phase (Fig. 4a). For a certain force value the load-bearing capacity of bended sheets is less than that of the riveting joint. After reaching this force value, sheets start to bend (Fig. 4b). Further tensile loading is continued with strongly bended sheets.

Blind rivet joints are formed in the similar conditions. However, in this case, it is difficult to maintain high repeatability of formation (the upsetting of the tubular part). Often the process of head formation is accidental [32]. Aluminum alloy sheets joined by a blind hermetic rivet in a tensile test behave in a similar way (Fig. 5a). In most cases (five out of seven specimens) the mechanism of fracture implies a pull-out of the rivet head from bottom sheets (Fig. 6a). In two other cases, the tubular part of a rivet exhibited a failure. This implies that the maximum strength of a joint was at the same level as the tubular part, in respect to the rivet maximum durability. In case of steel sheets (Fig. 5b), five out of seven specimens underwent a failure of the tubular part of a rivet in unilateral tensile tests (Fig. 6b). The yield strength $R_{e}$ of DC01 steel is higher than that of AW-5754 alloy by $75 \mathrm{MPa}(88 \%)$. Therefore, fracture of the joint of steel sheets was caused by the rivet failure (five out of seven specimens). However, during the tensile test of a hybrid joint 


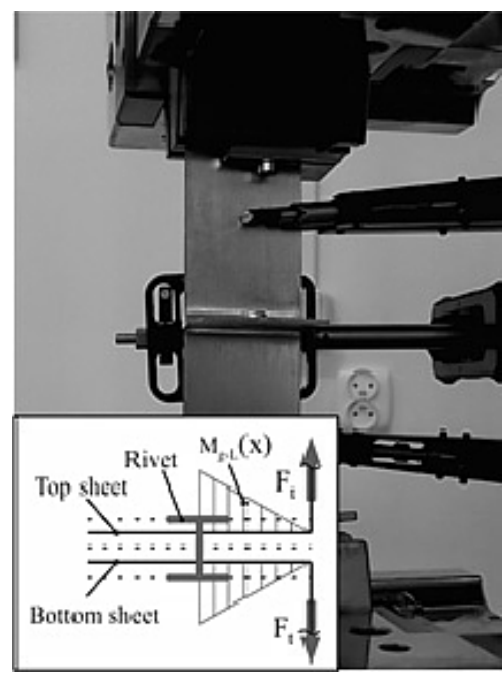

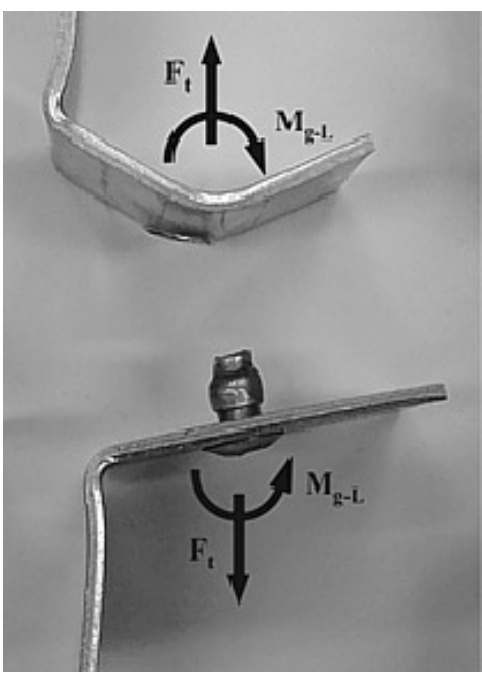

b

Fig. 4. The tensile test of T-specimens and the loading conditions: (a) T-specimen in the holder; (b) joint after tensile test.

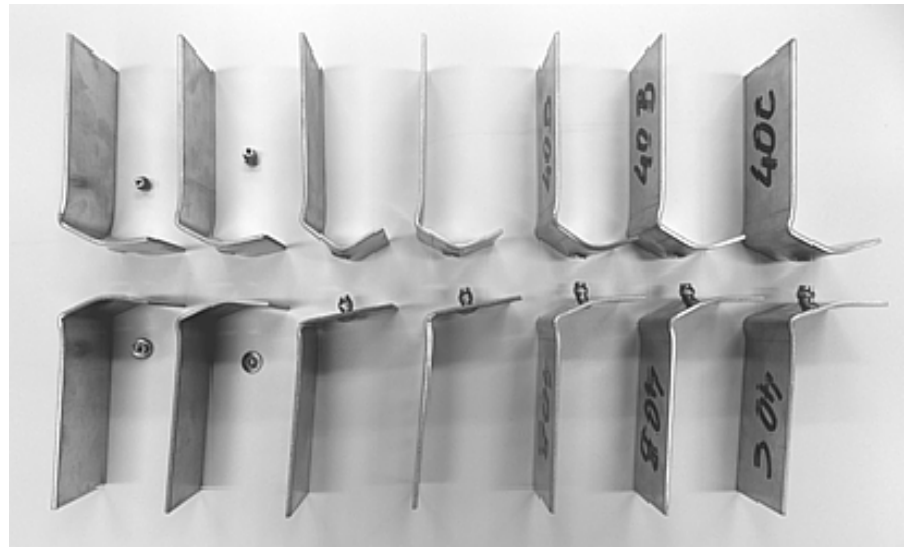

a

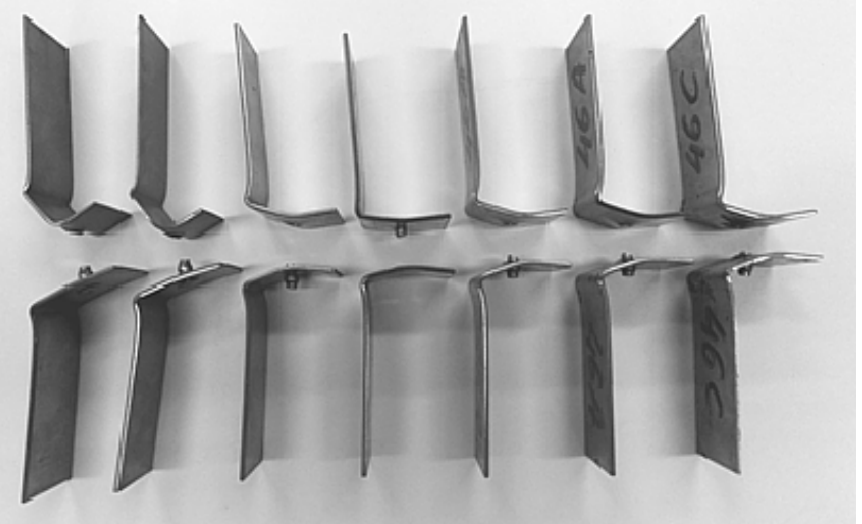

b

Fig. 5. The BHR joint after a unilateral tensile test. The sheet material: (a) AW-5754; (b) DC01. 


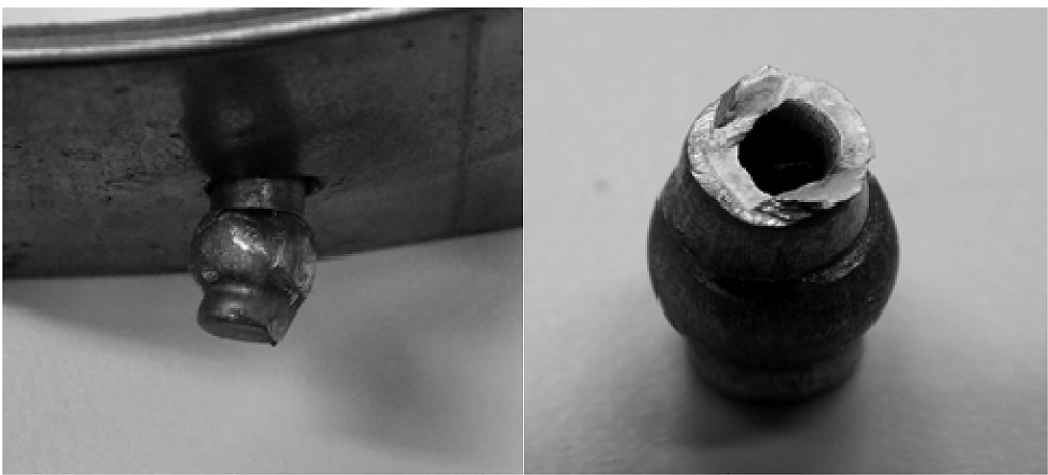

b

Fig. 6. The BHR surface of the upturned part (a) and crack surface (b).

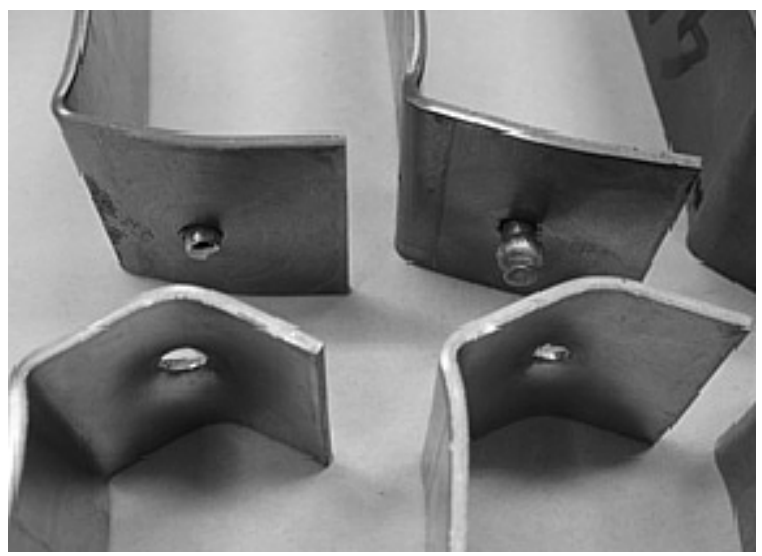

Fig. 7. The joint of sheet material DC01/AW-5754 with the BHR after the tensile test.

(combination of two materials: DC01 and AW-5754) two damage mechanisms were observed. The most common case was the rivet tubular part failure, while the second one, which occurred sporadically, was a fastener being pulled out from the bottom sheet (Fig. 7). Hence, the conclusion is that the load-bearing capacity of the joint is at the same level as the rivet tubular part and aluminum alloy (AW-5754) strength values.

The BR joint capacity conditions (Fig. 8) are as follows:

$$
\begin{gathered}
p_{1}^{\prime}=\sigma_{r}^{\prime}, \\
p_{1}^{\prime} \geq p_{2}^{\prime}, \\
p_{1}^{\prime} \geq \tau_{t 2}^{\prime} \geq \tau_{t 1}^{\prime},
\end{gathered}
$$

and for the COUR:

$$
\begin{gathered}
\sigma_{r} \geq p_{1}, \\
p_{2} \geq p_{1}, \\
\tau_{t 2} \geq \tau_{t 1} .
\end{gathered}
$$




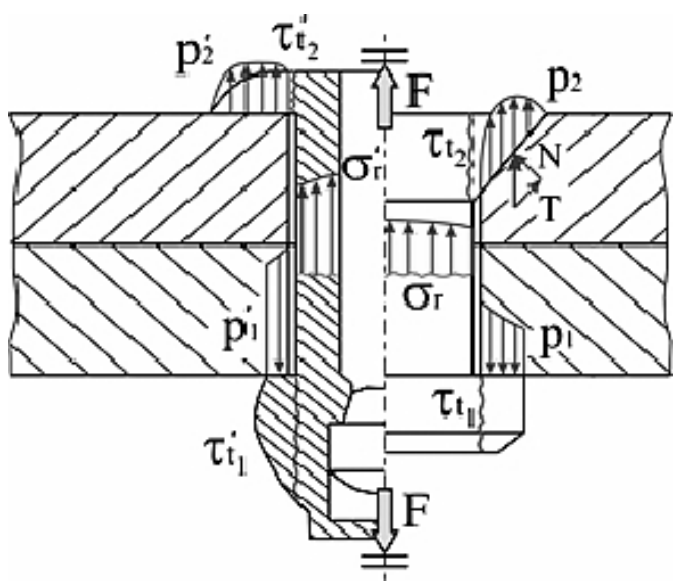

Fig. 8. The COUR and BR loading conditions.

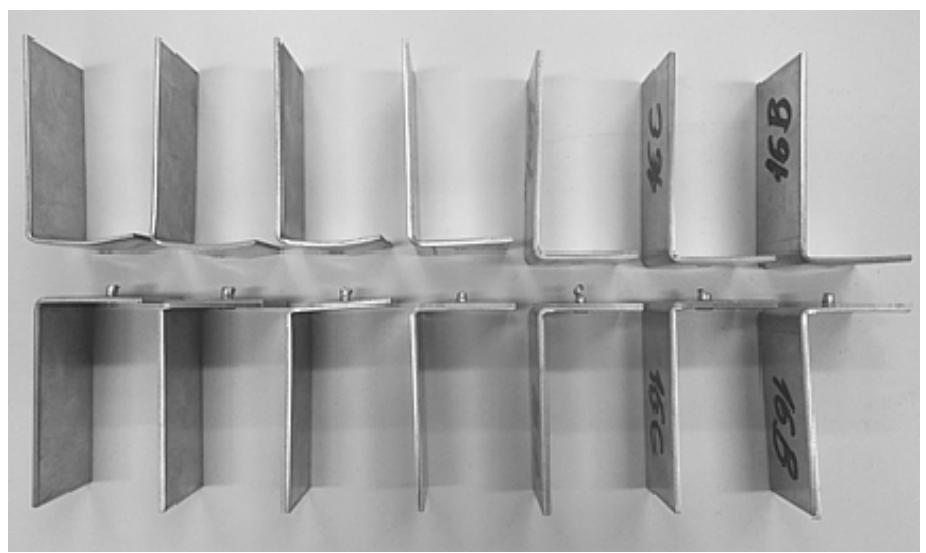

Fig. 9. The COUR joint after a unilateral tensile test (the sheet material: AW-5754).

During unilateral tensile tests of the AW-5754 sheet being joined by the closing-up rivet, the specimens exhibited a high stiffness, so that the rivet head failed (Fig. 9). The maximum strength of a joint was the same for the seven specimens. A similar mechanism of fracture was observed in the closing-up rivet for other sheet material arrangements. As the rivet under study had a conical part for its insertion into the hole, some hole chamfers were prepared, while the BR and SSPR rivets required no such hole preparations. The formed rivet head, despite its small height, was not sheared due to significant strengthening of the material. The flat rivet head in the hole of a conical part was upturned, and there were tensile stresses at the surface near the head. After the joint formation large residual stresses were concentrated in the rivet head, where the conical part changes into the cylindrical one [33]. Finally, the rivet failure occurred by separation of the head and the tubular part (Fig. 10). The residual stress concentration has a high impact on the joint fracture mechanism. During the tensile test, the residual stresses and the load-induced stresses are superimposed.

For the SSPR joint, the same mechanism of fracture was exhibited in the unilateral tensile tests (Fig. 11). Irrelevant of the sheet material arrangement, the force-displacement curves of high repeatability were obtained (Fig. 12). In the unilateral tensile tests, the rivet is loaded at one-side, hence the rivet head failure is likely to occur [20]. For properly selected parameters of formation (forming force) of the SSPR joint, a high repeatability of 


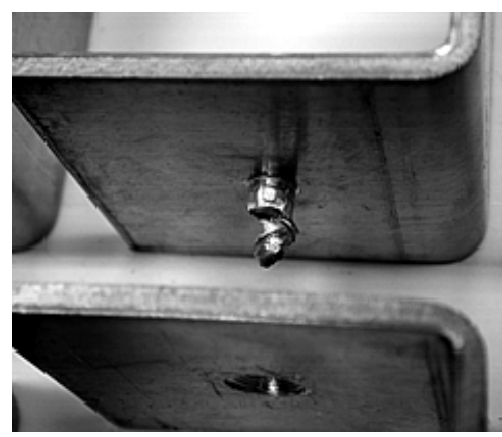

Fig. 10. The primary head failure of the COUR.

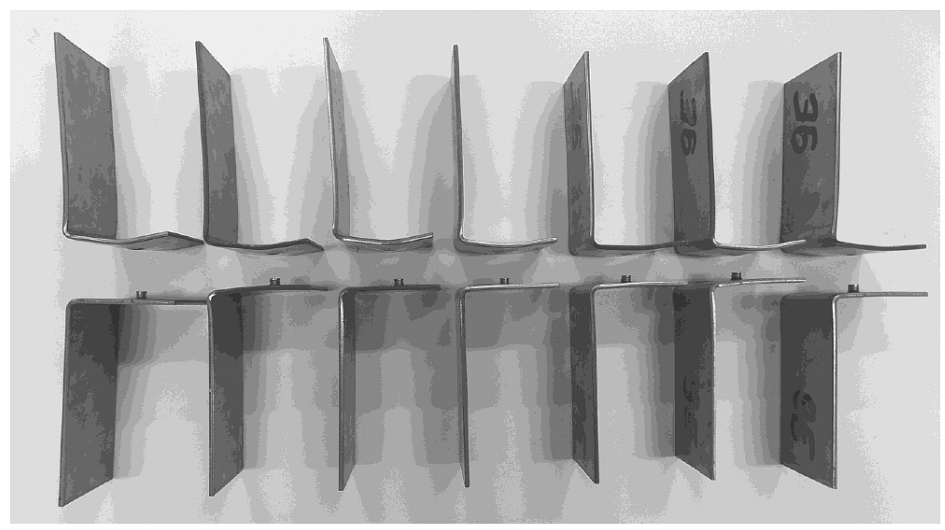

Fig. 11. The SSPR joint after a unilateral tensile test. The sheet material: DC01.

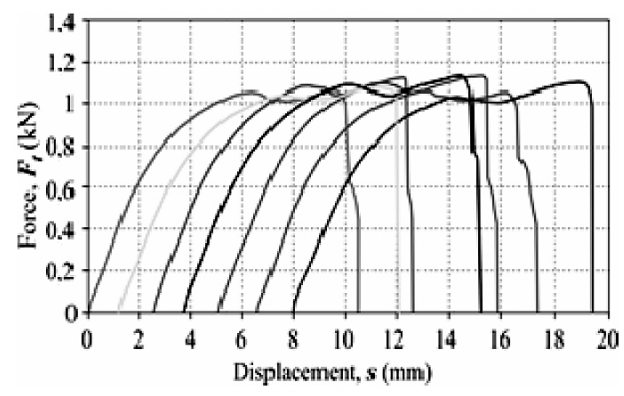

a

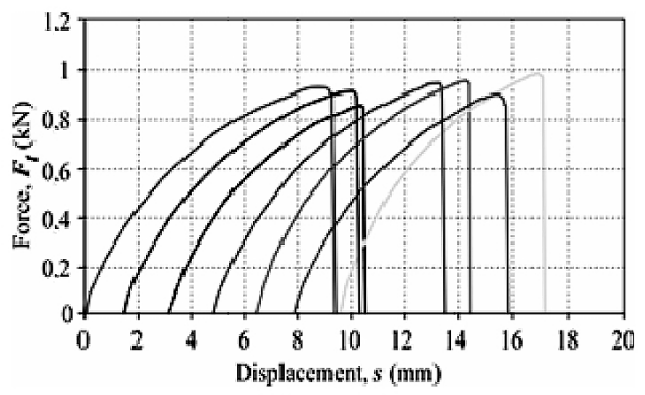

b

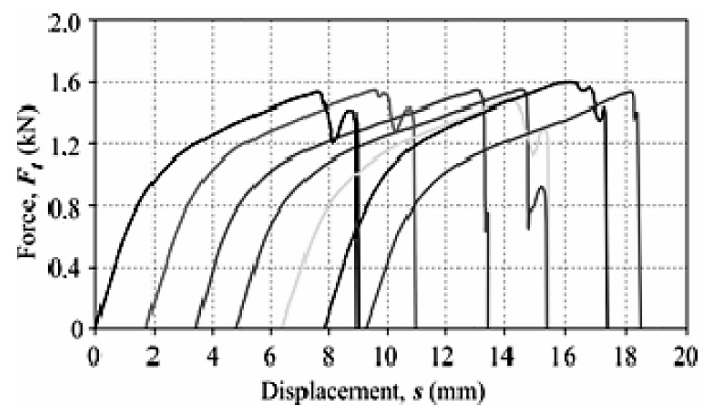

$\mathrm{c}$

Fig. 12. The SSPR tensile curves for different combinations of sheet materials: (a) DC 01/AW-5754; (b) AW-5754/AW-5754; (c) DC01/DC01. 
joint load-bearing capacity by the same joint fracture mechanism can be obtained. During the tensile test of T-shaped specimens the fastener was pulled out from the bottom sheet by shear of the sheet material within the grooves (Fig. 13). Thus, the sheet material type (especially bottom sheet) determined (in addition to the forming force of a joint) the capacity of the joint maximum load.

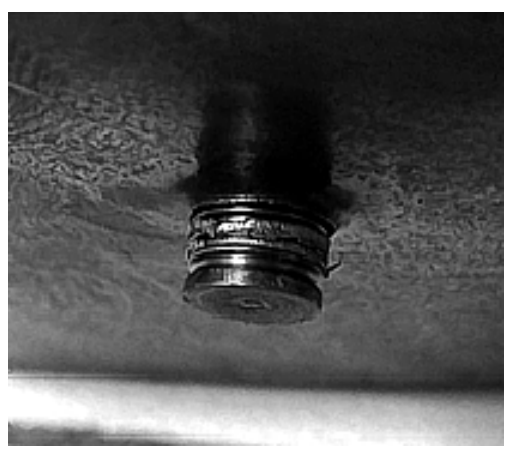

Fig. 13. The SSPR shank surface with the truncated bottom sheet material visible fragments.
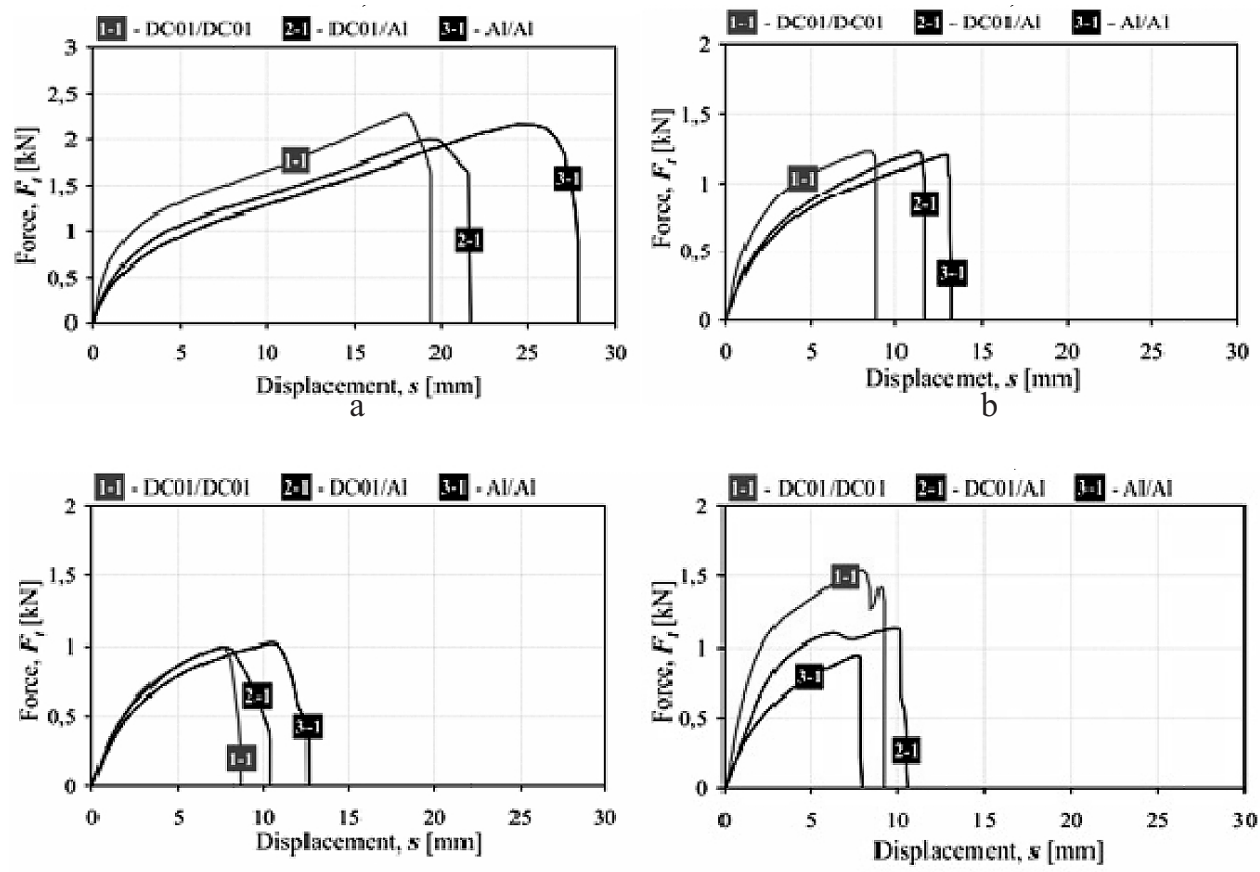

$\mathrm{c}$

d

Fig. 14. The tensile test joint curves for the different arrangements of sheet materials and joining systems (I - steel/steel, II - aluminum/steel, and III - aluminum/aluminum): (a) BHR; (b) BR; (c) COUR; (d) SSPR.

2.2. Joint Load-Bearing Capacity in Shear and Tensile Tests. Force-displacement curves obtained have a similar form in the tensile tests of different sheet arrangements for all three joint types (with blind rivet, blind hermetic rivet, and closing-up rivet), as is shown in Fig. 14a-c. The maximum forces of joint separation were nearly identical. The differences in the maximum force of a joint load and the total dissipation energy were obtained for the SSPR joint of steel, aluminum alloy and hybrid arrangements (Fig. 14d). 


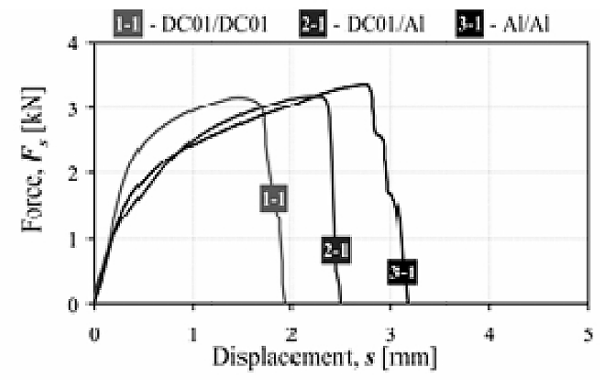

a

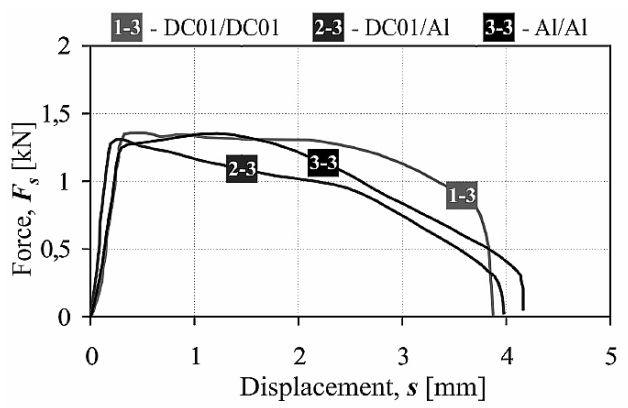

$\mathrm{c}$

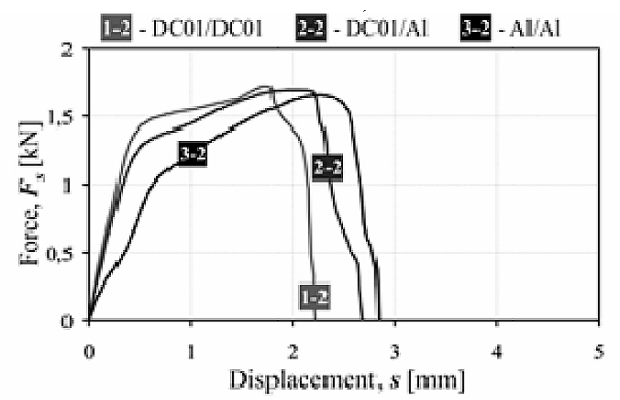

$\mathrm{b}$

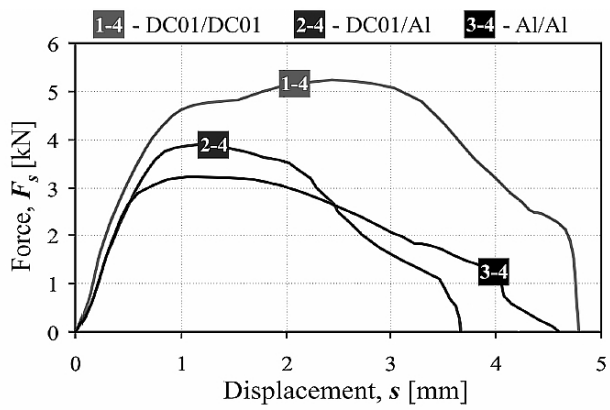

d

Fig. 15. The shear test joint curves for the different arrangements of sheet materials and joining systems: (a) BHR; (b) BR; (c) COUR; (d) SSPR.

a

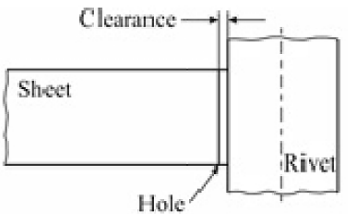

b

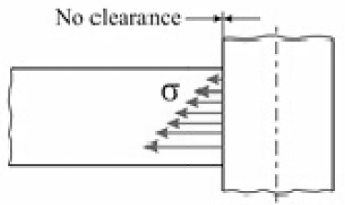

No secondary bending

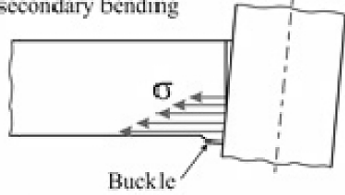

Secondary bending

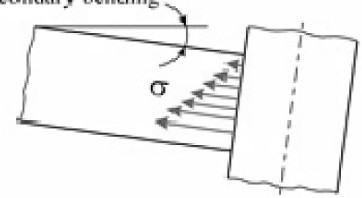

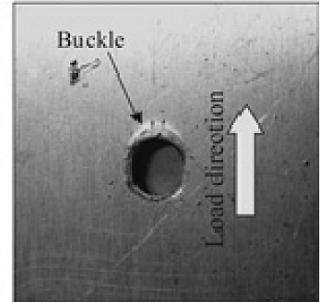

$\mathrm{c}$

Fig. 16. The rivet impact on the sheet metal hole surface: (a) without clearance; (b) with clearance; (c) the deformed hole in the aluminum alloy sheet after the joint shear test.

The sheet material in joint grooves was subjected to shear during the joint loading. After pulling-out from the bottom sheet, the remaining sheet material can be observed at the rivet surface.

The maximum forces of the joint loadings reached close values for the particular rivet type and three different sheet arrangements (Fig. 15a, b). However, the force-displacement curves had different shapes (Fig. 15a-d). The highest values of the total dissipation energy were obtained for the EN AW-5754 sheet material, and the lowest value for the DC01 sheet material - for joints with BR (Fig. 15a, b). For the joints with COUR the forcedisplacement curves of the shear test had similar forms (Fig. 15c), so the total dissipation energy values were nearly identical. The fasteners exhibited such a low strength, in relation to the sheet material, that the mechanisms of fracture of joints were the same during the tests. The highest stress concentration was observed at the joint shear surface (Fig. 16a, b). 


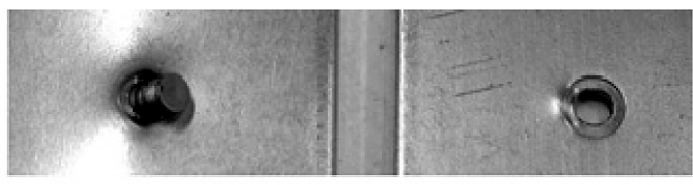

$\mathrm{b}$

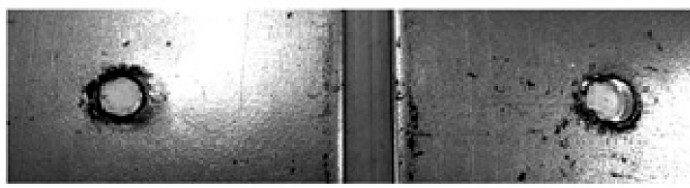

$\mathrm{c}$

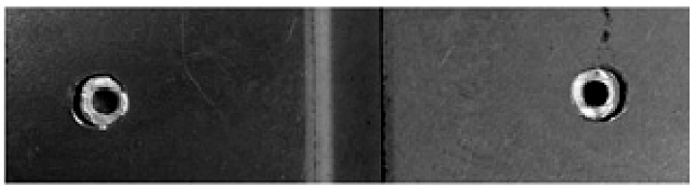

d

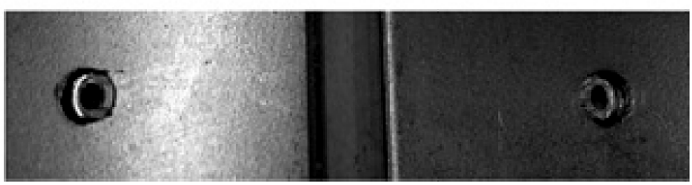

Fig. 17. The contact surface view after the shear test of the steel sheet material: (a) with SSPR joint; (b) with COUR joint; (c) with BHR joint; (d) with BR joint.

The stress concentration factor depends on several parameters, including clearance/gap between the rivet and the hole. In a riveting joint, the hole diameter is larger than that of the rivet. The clearance between them makes the rivet rotate during the joint loading (Fig. 16a). When the load increases, the contact area increases as well, whereas the stress level decreases. The sheet material is being upset at the hole surface. At the same time, the cylindrical shape of a hole changes into the oval one (Fig. 16c). If the sheets are bended, the stress concentration factor will be reduced. The mechanism of the stress concentration is depicted in Fig. 16b. The second factor causing the stress concentration of the hole surface is a secondary bending, as a result of the lack of a uniform head shape of a primary and secondary rivet. The unequal levels of stress at the contact between the rivet and the sheets result in sheet bending. The hole surface areas are deformed during the shear tests of the sheet material EN AW-5754 joined by a blind rivet and a closing-up rivet. When the rivet in the transverse cross section of the load capacity was reached, the rivet failed. The greatest hole deformations were observed for the aluminum alloy sheet material (Fig. 16c). Hole ovalization in the lap joints with a larger number of fasteners can occur in different varieties, depending on the number of rivet rows [34-36]. There is no clearance between a rivet and a hole in the SSPR joints, and the head is present only at one side of the rivet. Therefore, there is a significant rivet rotation and bending of the sheet so that pulling out the rivet from the bottom sheet is possible. Thus, after separation of the lap joint, the rivet rotation and significant hole deformation are observed (Fig. 17a). One of the most vexing problems confronting a structural designer is the design of joints. To first order, the objective in joint design is to maximize the joint efficiency $\eta$ :

$$
\eta=\frac{\text { Failure load of the joint }}{\text { Failure load of the surrounding sheet }} .
$$

The joint true efficiency is the minimum of all the possible joint efficiencies one can calculate for all possible failure modes of the joint (Fig. 1). For the riveting joints, the 
maximum capacity of the surface load of the sheet material should be higher than that controlled by the shear stress of a rivet material. This relation allows one to predict the joint strength based on the rivet shear condition using a certain ratio of the sheet thickness and the hole diameter:

$$
\frac{\pi d^{2}}{4} m n k_{t} \leq n t d k_{0}
$$

where $m$ is the number of the rivet transverse cross sections subject to shear, $n$ is the number of rivets in the joint, $t$ is the thickness of the thinner sheet, $d$ is the rivet/hole diameter, $k_{0}$ is the allowable surface pressure of the sheet material, and $k_{t}$ is the allowable rivet material shear stress.

Assuming that $k_{0}=2.5 k_{t}$ we obtained the following condition:

$$
\frac{d}{t} \leq \frac{3.2}{m}
$$

For unilateral rivets under shear loading - the lap joint (the number of rivet transverse cross sections sheared) $m=1$, hence the condition is $d_{0}<3.2 t$, while for the strapped joint $m=2-$ thus, $d_{0}<1$. $6 t$. If this relation is satisfied, then the maximum load-bearing capacity can be calculated from the shear condition. When the rivet fills the hole, a uniform load-bearing pressure distribution exists in the thickness direction of the sheet. The increased clamping is beneficial with respect to improving the load transfer by friction between the contacting surfaces of sheets.

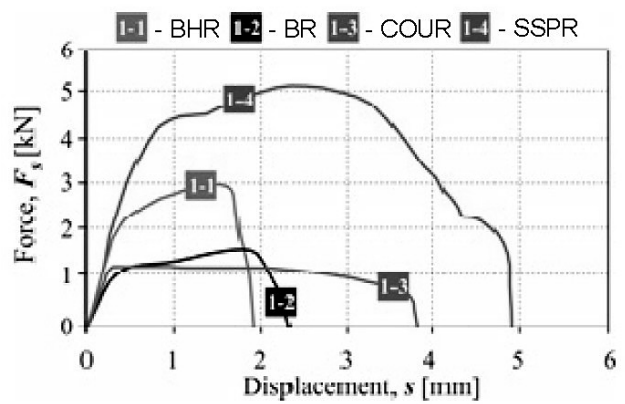

a

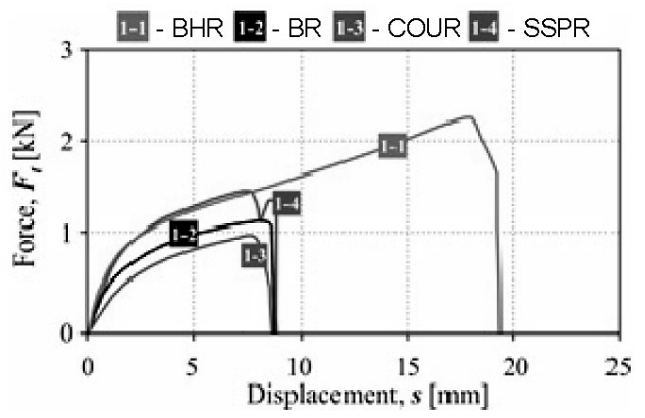

b

Fig. 18. The joint force characteristic of DC01/DC01 steel sheet: (a) shear test; (b) tensile test.

Designers of thin-walled structures often have a dilemma as to which types of rivet should be used, in order to provide the specified load-bearing capacity. Sometimes, they make use of fasteners, which are already used in the company, without paying attention to the rivet diameter and the sheet thickness. The mechanism of fracture of a joint presented above does not include the fourth joint type with the SSPR. Since a self-piercing rivet is punching a hole, it must have an appropriate hardness, e.g., $58 \mathrm{HRC}$ [20]. In this type of joints, the rivet rotates and is pulled out from the bottom sheet (Fig. 17a). In case of aluminum alloy sheets, the lowest values of the maximum tensile shear force are obtained (Fig. 15d). The joint load capacity depends on the mechanical properties of the sheet material, rather than those of the rivet material. To present the capabilities of shear and tensile load-bearing capacity of the four selected joining techniques, the steel sheet specimens were chosen (Fig. 18). The highest value of the shear force was obtained for the SSPR joints, and the lowest one for the joint with the closing-up rivet. The capacities of a 

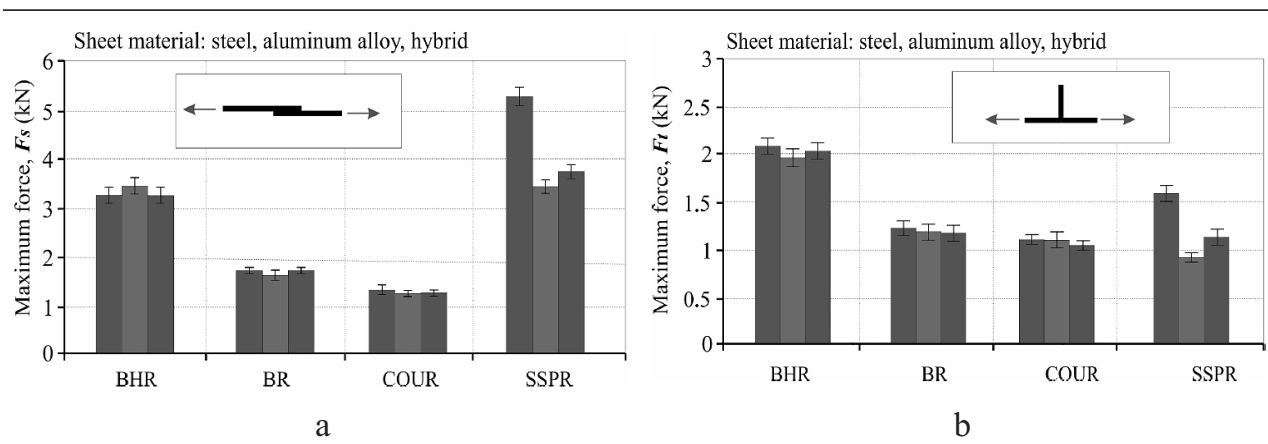

Fig. 19. The arithmetic average of the maximum tensile force.

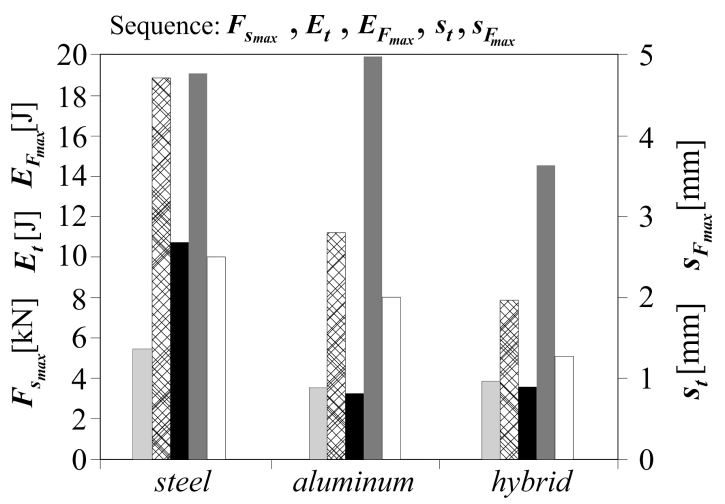

Fig. 20. The SSPR joint shear strength for different sheet materialss. $\left(F_{S_{\max }}\right.$ is the maximum tensile shear load, $E_{t}$ is the dissipated energy, $E_{F_{\max }}$ is the dissipated energy up to maximum tensile shear load, $s_{t}$ is the total displacement, $s_{F_{\max }}$ is the displacement at the maximum tensile shear load.)

tensile load transfer are lower than those of a shear transfer. In tensile tests, the maximum values of the joint fracture force were observed for the steel sheets joined by the blind hermetic rivet (Fig. 18b). For this joint type, the dissipated energy is the highest. The rivet failure occurred in the tubular part near the rivet head. In shear tests, the SSPR joints were more durable than others. For the SSPR joints the differences in the maximum shear and tensile forces were observed for variable sheet arrangements (Fig. 19). The average value of shear force for the DC01 material was $5.26 \mathrm{kN}$ and for the EN AW-5754-3.42 kN. In this case, the value variation was $35 \%$. For the sheet thickness of $2 \mathrm{~mm}$ and equal forming force $30 \mathrm{kN}$, the largest difference between shear and tensile forces was obtained for DC01 material $(3.73 \mathrm{kN})$. For the combination of EN AW-5754 and DC01 sheet materials (hybrid joint) the difference was $2.64 \mathrm{kN}$, and for EN AW-5754 aluminum alloy this difference was $2.52 \mathrm{kN}$. For other joints with blind and closing-up rivets there was no significant influence of the sheet material arrangements on the maximum loading force of the joint. Out of seven tests, the largest difference in the average values of shear and tensile forces was obtained for the SSPR joints (Fig. 19). Hence, for these joints the selected indicators from the lap shear test were presented according to the ISO/FDIS 12996 standard [22]. The highest value of dissipated energy was obtained for the steel sheet material, and the lowest value for the hybrid sheet arrangement (Fig. 20). When the bottom sheet material was replaced from steel by aluminum alloy, the total dissipated energy decreased by $58 \%$. For the SSPR joint, the normal distribution curve and frequency of the maximum joint strength are depicted in Fig. 21. 

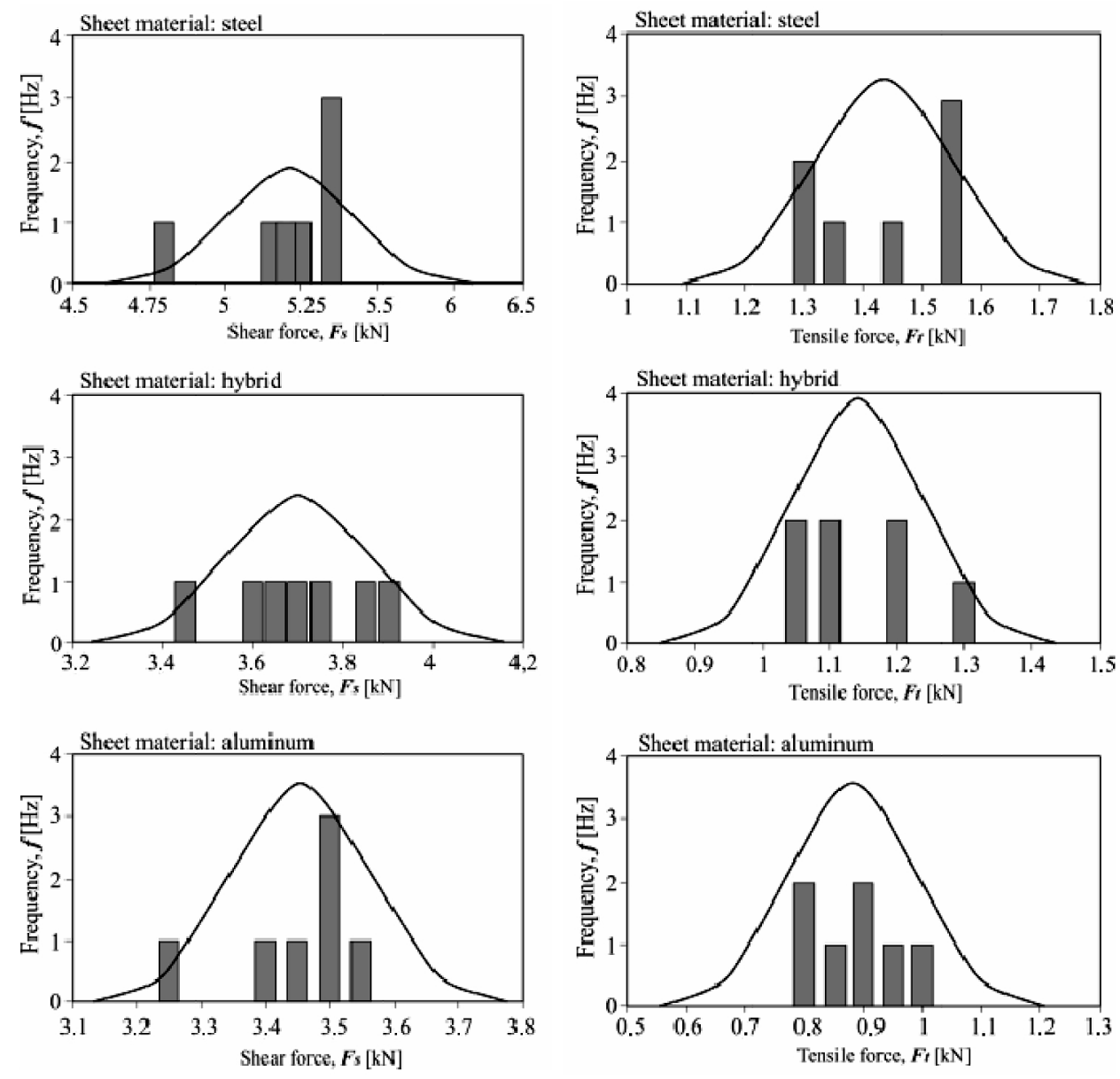

$\mathrm{a}$

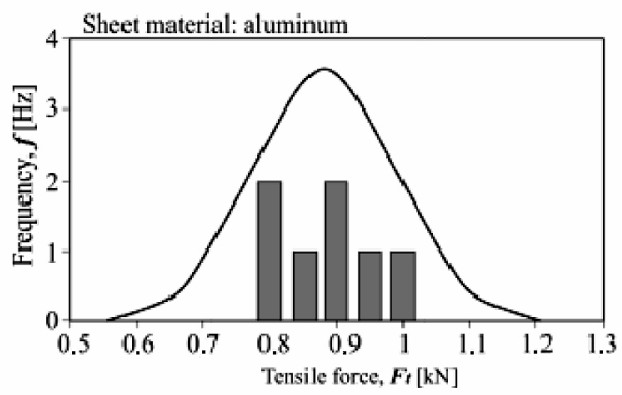

b

Fig. 21. The maximum shear (a) and tensile (b) strength normal probability density distributions for SSPR joints.

Conclusions. This paper presents the experimental analysis of the capacity of a joint load for four different rivets and the statistical analysis of the results. The most important conclusions are:

1. For joints with conventional rivets, the same level connection strength is reached, regardless of the joint sheet materials. The fastener strength corresponds to the maximum load-bearing capacity of the joints.

2. For the joints with tubular BR, the maximum load-bearing capacity is reached at the sheet material limit (from the rivet secondary head) and the tensile strength limit of the rivet tubular part.

3. For the SSPR joints, the joint strength depends on the mechanical properties of the joined sheets. It is highest for steel sheets and lowest for the aluminum alloy sheets.

4. For the SSPR joints, rivets are is pulled out in tensile tests of T-shaped specimens. In shear tests, rivets are turned and pulled out from the sheet material. There was no SSPR failure. In case of other rivets, fastener failed was always observed.

Acknowledgments. This work was prepared in cooperation with the Department of Mechanical Engineering, Rzeszow University of Technology with AGRMAR S.A. company headquartered in Mielec. The authors thank the company employees for the assistance in 
the laboratory researches. They also thank Prof. Sieniawski (Head of the Research and Development Laboratory for Aerospace Materials-LabMatPL) for making the test machine available to our tests.

\section{Резюме}

Основним критерієм міцності заклепочних з'єднань при їх розробці є опір матеріалу заклепок зсувному навантаженню. При випробуваннях на зсув звичайних заклепочних з'єднань визначальними $€$ механічні характеристики матеріалу заклепки. У зв'язку з цим необхідно описання механізму руйнування різних з'єднань при випробуваннях на розтяг. Оцінюється міцність різних листових матеріалів (сталь DC01, алюмінієвий сплав AW-5754 та їх комбінація) у заклепочних з'єднаннях. Аналізується механізм руйнування заклепочних з'єднань при одновісному розтязі Т-подібних зразків із різних листових матеріалів. Виконано порівняння експериментальних результатів, отриманих при розтязі і стиску заклепочних з’єднать внапуск для одного і того ж типу.

1. J. Mucha and W. Witkowski, "The experimental analysis of the double joint type change effect on the joint fracture process in uniaxial shear test," Thin-Walled Struct., 66, 39-49 (2013).

2. A. Bayan, S. Sariffuddin, and O. Hanim, "Cold formed steel joints and structures - a review," Int. J. Civil Struct. Eng., 2, No. 2, 621-634 (2011).

3. W. Lu, P. Makelainen, J. Outinen, and Z. Ma, "Design of screwed steel sheeting connection at ambient and elevated temperatures," Thin-Walled Struct., 49, 15261533 (2011).

4. P. Childs, Mechanical Design Engineering Handbook, Ch. 16: Fastening and Power Screws, Elsevier (2014), pp. 677-719.

5. R. Matsuzaki, M. Shibata, and A. Todoroki, "Improving performance of GFRP/ aluminum single lap joints using bolted/co-cured hybrid method," Composites: Part A, 39, 154-163 (2008).

6. B. Kolesnikov, L. Herbeck, and A. Fink, "CFRP/titanium hybrid material for improving composite bolted joints," Compos. Struct., 83, 368-380 (2008).

7. M. L. Dano, G. Gendron, and A. Picard, "Stress and failure analysis of mechanically fastened joints in composite laminates," Compos. Struct., 50, 287-296 (2000).

8. F. Moroni, A. Pirondi, and F. Kleiner, "Experimental analysis and comparison of the strength of simple and hybrid structural joints," Int. J. Adhes. Adhesiv., 30, 367-379 (2010).

9. G. Di Franco, L. Fratini, and A. Pasta, "Influence of the distance between rivets in self-piercing riveting bonded joints made of carbon fiber panels and AA2024 blanks," Mater. Des., 35, 342-349 (2012).

10. G. Di Franco, L. Fratini, and A. Pasta, "Analysis of the mechanical performance of hybrid (SPR/bonded) single-lap joints between CFRP panels and aluminum blanks," Int. J. Adhes. Adhesiv., 41, 24-32 (2013).

11. M. Ueda, S. Miyake, H. Hasegawa, and Y. Hirano, "Instantaneous mechanical fastening of quasi-isotropic CFRP laminates by a self-piercing rivet," Compos. Struct., 94, 3388-3393 (2012).

12. N. Wagner, in: K.-H. Grote and E. K. Antonsson (Eds.), Springer Handbook of Mechanical Engineering, Springer-Verlag, Berlin-Heidelberg (2009), pp. 686-697. 
13. R. Neugebauer, M. Todtermuschke, R. Mauermann, and F. Riedel, "Overview on the state of development and the application potential of dieless mechanical joining processes," Arch. Civil. Mech. Eng., 4, 51-60 (2008).

14. N. Nong, O. Keju, Z. Yu, et al., "Research on press joining technology for automotive metallic sheets," J. Mater. Process. Technol., 137, No. 1-3, 159-163 (2003).

15. W. Voelkner, F. Jesche, and L. Lachmann, "Joining by forming: newer developments," J. Technol. Plast., 1-2, 5-17 (2002).

16. S. Gao and L. Budde, "Mechanism of mechanical press joining," Int. J. Mach. Tool. Manuf., 5, 641-657 (1994).

17. X. He, I. Pearson, and K. Young, "Self-pierce riveting for sheet materials: state of the art," J. Mater. Process. Technol., 199, 27-36 (2008).

18. J. Mucha, "A study of quality parameters and behavior of self-piercing riveting aluminium sheets with different joining conditions," Strojn. Vestn. (J. Mech. Eng.), 57, 323-333 (2011).

19. www.kerbkonus (01.01.2013).

20. J. Mucha, "The effect of material properties and joining process parameters on behavior of self-pierce riveting joints made with the solid rivet," Mater. Des., 52, 932-946 (2013).

21. J. Mucha, "The numerical analysis of the effect of the joining process parameters on self piercing riveting using the solid rivet," Arch. Civil. Mech. Eng., 14, 444-454 (2013).

22. R. Neugebauer, F. Jesche, and M. Israel, "Enlargement of the application range of solid punch riveting by two-piece dies," Int. J. Mater. Form., 3, 999-1002 (2010).

23. G. Meschut, V. Janzen, and T. Olfermann, "Innovative and highly productive joining technologies for multi-material lightweight car body structures," J. Mater. Eng. Perform., 23, No. 5, 1515-1523 (2014).

24. ISO/FDIS 12996. Mechanical Joining - Destructive Testing of Joints - Specimen Dimensions and Test Procedure for Tensile Shear Testing of Single Joints (2013).

25. ASTM D5961/D5961M-13: Standard Test Method for Bearing Response of Polymer Matrix Composite Laminates, ASTM International, West Conshohocken, PA (2013).

26. EN 1993-1-8. Eurocode 3. Design of Steel Structures. Part 1-8: Design of Joints (2005).

27. X. He and B. Xing, "The ultimate tensile strength of coach peel self-piercing riveting joints," Strength Mater., 45, No. 3, 386-390 (2013).

28. R. Porcaro, A. G. Hanssen, M. Langseth, and A. Aalberg, "The behaviour of a self-piercing riveting connection under quasi-static loading conditions," Int. J. Solids Struct., 43, 5110-5131 (2006).

29. B. Bartczak, J. Mucha, and T. Trzepieciński, "Stress distribution in adhesively-bonded joints and the loading capacity of hybrid joints of car body steels for the automotive industry," Int. J. Adhes. Adhesiv., 45, 42-52 (2013).

30. J. Mucha and W. Witkowski, "The clinching joints strength analysis in the aspects of the changes in the forming technology and the load conditions," Thin-Walled Struct., 82, 55-66 (2014).

31. S. Hossein Cheraghi, "Effect of variations in the riveting process on the quality of riveting joints," Int. J. Adv. Manuf. Technol., 39, 1144-1155 (2008).

32. B. Kelly and C. Costello, "FEA modeling of setting and mechanical testing of aluminum blind rivets," J. Mater. Process. Technol., 153-154, 74-79 (2004). 
33. V. Blanchot and A. Daidie, "riveting assembly modelling: Study and numerical characterisation of a riveting process," J. Mater. Process. Technol., 180, No. 1-3, 201-209 (2006).

34. C. C. Menzemer, L. Fei, and T. S. Srivatsan, "Failure of bolted connections in an aluminum alloy," J. Mater. Eng. Perform., 8, 197-204 (1999).

35. M. Džupon, L. Falat, J. Slota, and P. Hvizdoš, "Failure analysis of overhead power line yoke connector," Eng. Fail. Anal., 33, 66-74 (2013).

36. C. C. Menzemer, L. Fei, and T. S. Srivatsan, "Mechanical response and failure of bolted connection elements in aluminum alloy 5083," J. Mater. Eng. Perform., 8, 211-218 (1999).

Received 05. 07. 2015 